Scientific paper

\title{
Synthesis, Crystal Structures and Antibacterial Activities of Trifluoromethylsulfonate Salts of 2-[(3-Chloropyridinium-2-yl)hydrazonomethyl]- 6-methoxyphenol and its Copper(II) and Cobalt(III) Complexes
}

\author{
Ya-Li Sang,* Xue-Song Lin and Wei-Dong Sun \\ Department of Chemistry and Chemical Engineering, Chifeng University, Chifeng 024001, P. R. China \\ * Corresponding author: E-mail: sangyali0814@126.com
}

Received: 05-08-2016

\begin{abstract}
A new trifluoromethylsulfonate salt of 2-[(3-chloropyridinium-2-yl)hydrazonomethyl]-6-methoxyphenol, $(\mathrm{HL}) \mathrm{CF}_{3} \mathrm{SO}_{3}$, and its copper(II) and cobalt(III) complexes, $\left[\mathrm{CuL}\left(\mathrm{OH}_{2}\right)\right] \mathrm{CF}_{3} \mathrm{SO}_{3} \cdot 0.5 \mathrm{H}_{2} \mathrm{O}(\mathbf{1})$ and $\left[\mathrm{CoL}_{2}\right] \mathrm{CF}_{3} \mathrm{SO}_{3} \cdot \mathrm{CH}_{3} \mathrm{OH}(\mathbf{2})$, were prepared and characterized by physico-chemical methods and single crystal X-ray analysis. A trifluoromethylsulfonate anion is present in each of the compounds. The $\mathrm{Cu}$ atom in complex $\mathbf{1}$ is coordinated by the phenolate $\mathrm{O}$, imino $\mathrm{N}$ and pyridine $\mathrm{N}$ atoms of $\mathrm{L}$ ligand, giving square planar geometry. The Co atom in complex $\mathbf{2}$ is coordinated by two phenolate $\mathrm{O}$, two imino $\mathrm{N}$ and two pyridine $\mathrm{N}$ atoms from two $\mathrm{L}$ ligands, giving octahedral geometry. The three compounds were tested in vitro for their antibacterial activities.
\end{abstract}

Keywords: Schiff base; Copper; Cobalt; Synthesis; Crystal structure; Antibacterial activity

\section{Introduction}

Schiff bases are readily synthesized by the condensation reaction of carbonyl compounds with primary amines. ${ }^{1}$ Schiff bases have been widely investigated for their biological activities, such as antibacterial and antitumor activities, ${ }^{2}$ biomimetic catalytic properties, etc. ${ }^{5}$ Metal complexes of Schiff bases have also received much attention. These complexes not only play an important role in the development of coordination chemistry related to catalysis and enzymatic reactions, magnetism and molecular architectures, ${ }^{4}$ but also exhibit interesting biological activities. $^{5}$

In recent years, a number of Schiff bases and their complexes have been reported. ${ }^{6}$ Most of the compounds show versatile biological properties especially antibacterial activities. ${ }^{7}$ It was reported that the compounds bearing halo-atoms on the aromatic ring have improved antibacterial and antifungal activities. ${ }^{8}$ In the present work, a new trifluoromethylsulfonate salt of 2-[(3-chloropyridinium2-yl)hydrazonomethyl]-6-methoxyphenol, (HL) $\mathrm{CF}_{3} \mathrm{SO}_{3}$, and its copper(II) and cobalt(III) complexes, [Cu-
$\left.\mathrm{L}\left(\mathrm{OH}_{2}\right)\right] \mathrm{CF}_{3} \mathrm{SO}_{3} \cdot 0.5 \mathrm{H}_{2} \mathrm{O}(\mathbf{1})$ and $\left[\mathrm{CoL}_{2}\right] \mathrm{CF}_{3} \mathrm{SO}_{3} \cdot \mathrm{CH}_{3} \mathrm{OH}$ (2), are prepared and characterized. The antibacterial activities against Bacillus subtilis, Staphylococcus aureus, Escherichia coli, and Pseudomonas fluorescens, were evaluated.<smiles>COc1cccc(/C=N/Nc2ncccc2Cl)c1O</smiles>

Scheme 1. The Schiff base ligand L

\section{Experimental}

\section{1. Materials and Measurements}

3-Methoxysalicylaldehyde and (3-chloropyridin-2yl)hydrazine with AR grade were obtained from Aldrich 
and used as received. Copper trifluoromethylsulfonate and cobalt trifluoromethylsulfonate were prepared by the reaction of trifluoromethylsulfonic acid with $\left[\mathrm{Cu}_{2}(\mathrm{OH})_{2} \mathrm{CO}_{3}\right]$ and $\mathrm{CoCO}_{3}$, respectively. Elemental analyses were performed using a Perkin-Elmer 240C analytical instrument. Infrared spectra were recorded on a Nicolet 5DX FT-IR spectrophotometer with $\mathrm{KBr}$ pellets. ${ }^{1} \mathrm{H}$ NMR spectra were recorded on a Bruker instrument at $400 \mathrm{MHz}$. Molar conductance was measured with a Shanghai DDS-11A conductometer.

\section{2. Synthesis of (HL) $\mathrm{CF}_{3} \mathrm{SO}_{3}$}

3-Methoxysalicylaldehyde $(1.52 \mathrm{~g}, 0.010 \mathrm{~mol})$ and (3-chloropyridin-2-yl)hydrazine $(1.43 \mathrm{~g}, 0.010 \mathrm{~mol})$ were mixed in methanol $(30 \mathrm{~mL})$. The mixture was stirred at room temperature and then evaporated to give yellow powder of L, which was washed three times with methanol and dried in air. Yield: 91\%. Anal. Calcd. for $\mathrm{C}_{13} \mathrm{H}_{12} \mathrm{ClN}_{3} \mathrm{O}_{2}(\%)$ : C, 56.2; H, 4.4; N, 15.1. Found: C, 56.4; $\mathrm{H}, 4.3 ; \mathrm{N}, 15.2 .{ }^{1} \mathrm{H}$ NMR $\left(d^{6}\right.$-DMSO): $\delta: 8.72(\mathrm{~s}$, $1 \mathrm{H}, \mathrm{CH}=\mathrm{N}), 8.18(\mathrm{~d}, 1 \mathrm{H}, \mathrm{NH}), 7.98(\mathrm{~d}, 1 \mathrm{H}, \mathrm{Py} H), 7.49(\mathrm{~d}$, $1 \mathrm{H}, \mathrm{Py} H), 7.23(\mathrm{~d}, 1 \mathrm{H}, \mathrm{Ar} H), 7.03-6.94(\mathrm{~m}, 2 \mathrm{H}, \operatorname{Ar} H)$, $6.87(\mathrm{t}, 1 \mathrm{H}, \mathrm{Py} H), 3.82$ (s, $\left.3 \mathrm{H}, \mathrm{OCH}_{3}\right)$. Single crystals were formed by addition of equimolar quantity of trifluoromethylsulfonic acid to the methanol solution of L. IR data $\left(\mathrm{KBr}, \mathrm{cm}^{-1}\right)$ : $3439 \mathrm{w}, 3300 \mathrm{w}, 1644 \mathrm{~m}, 1594 \mathrm{~m}, 1518 \mathrm{~m}$, $1456 \mathrm{~s}, 1407 \mathrm{~s}, 1358 \mathrm{~s}, 1253 \mathrm{~m}, 1157 \mathrm{~s}, 1073 \mathrm{~s}, 949 \mathrm{~s}, 858 \mathrm{~s}$, $733 \mathrm{w}, 629 \mathrm{w}, 543 \mathrm{~s}, 526 \mathrm{~s}, 470 \mathrm{~m}$.

\section{3. Synthesis of $\left[\mathrm{CuL}\left(\mathrm{OH}_{2}\right)\right] \mathrm{CF}_{3} \mathrm{SO}_{3}$. $0.5 \mathrm{H}_{2} \mathrm{O}$ (1)}

To a methanolic solution $(10 \mathrm{~mL})$ of $\mathrm{L}(27.7 \mathrm{mg}$, $0.10 \mathrm{mmol})$, an aqueous solution $(2 \mathrm{~mL})$ of copper trifluoromethylsulfonate $(36.2 \mathrm{mg}, 0.10 \mathrm{mmol})$ was added with stirring. The mixture was stirred for half an hour and filtered. The filtrate was kept undisturbed at room temperature to slow evaporate for seven days, generating blue crystals suitable for X-ray diffraction. Crystals were isolated by filtration and dried in air. Yield $38 \%$ with respect to $\mathrm{L}$. Anal. Calcd. for $\mathrm{C}_{28} \mathrm{H}_{28} \mathrm{Cl}_{2} \mathrm{Cu}_{2} \mathrm{~F}_{6} \mathrm{~N}_{6} \mathrm{O}_{13} \mathrm{~S}_{2}(\%)$ : $\mathrm{C}, 32.6 ; \mathrm{H}$, 2.7; N, 8.1. Found: C, 32.8; H, 2.8; N, 8.0. IR data $(\mathrm{KBr}$, $\mathrm{cm}^{-1}$ ): $3453 \mathrm{~m}, 1622 \mathrm{~m}, 1538 \mathrm{~m}, 1449 \mathrm{~m}, 1253 \mathrm{~s}, 1157 \mathrm{~s}$, $1066 \mathrm{~s}, 956 \mathrm{~s}, 858 \mathrm{~s}, 782 \mathrm{w}, 741 \mathrm{w}, 636 \mathrm{~m}, 576 \mathrm{~s}$.

\section{4. Synthesis of $\left[\mathrm{CoL}_{2}\right] \mathrm{CF}_{3} \mathrm{SO}_{3} \cdot \mathrm{CH}_{3} \mathrm{OH}$ (2)}

To a methanolic solution $(10 \mathrm{~mL})$ of $\mathrm{L}(27.7 \mathrm{mg}$, $0.10 \mathrm{mmol})$, an aqueous solution $(2 \mathrm{~mL})$ of cobalt trifluoromethylsulfonate $(35.7 \mathrm{mg}, 0.10 \mathrm{mmol})$ was added with stirring. The mixture was stirred for half an hour and filtered. The filtrate was kept undisturbed at room temperature to slow evaporate for seven days, generating brown crystals suitable for X-ray diffraction. Crystals were isolated by filtration and dried in air. Yield $45 \%$ with respect to $\mathrm{L}$. Anal. Calcd. for $\mathrm{C}_{28} \mathrm{H}_{26} \mathrm{Cl}_{2} \mathrm{CoF}_{3} \mathrm{~N}_{6} \mathrm{O}_{8} \mathrm{~S}$ (\%): C, 42.4; $\mathrm{H}$, 3.3; N, 10.6. Found: C, 42.5; H, 3.4; N, 10.4. IR data (KBr, $\left.\mathrm{cm}^{-1}\right): 3467 \mathrm{~m}, 1615 \mathrm{~m}, 1538 \mathrm{~m}, 1449 \mathrm{~m}, 1365 \mathrm{w}, 1295 \mathrm{w}$, $1247 \mathrm{w}, 1164 \mathrm{~s}, 1073 \mathrm{~s}, 949 \mathrm{~s}, 858 \mathrm{~s}, 734 \mathrm{w}, 637 \mathrm{w}, 533 \mathrm{~s}$.

Table 1. Crystallographic and experimental data for the compounds

\begin{tabular}{|c|c|c|c|}
\hline Compound & $(\mathrm{HL}) \mathrm{CF}_{3} \mathrm{SO}_{3}$ & 1 & 2 \\
\hline Chemical formula & $\mathrm{C}_{14} \mathrm{H}_{13} \mathrm{ClF}_{3} \mathrm{~N}_{3} \mathrm{O}_{5} \mathrm{~S}$ & $\mathrm{C}_{28} \mathrm{H}_{28} \mathrm{Cl}_{2} \mathrm{Cu}_{2} \mathrm{~F}_{6} \mathrm{~N}_{6} \mathrm{O}_{13} \mathrm{~S}_{2}$ & $\mathrm{C}_{28} \mathrm{H}_{26} \mathrm{Cl}_{2} \mathrm{CoF}_{3} \mathrm{~N}_{6} \mathrm{O}_{8} \mathrm{~S}$ \\
\hline Formula weight & 427.8 & 1032.7 & 793.4 \\
\hline crystal system & monoclinic & triclinic & triclinic \\
\hline space group & $P 2_{1} / c$ & $P-1$ & $P-1$ \\
\hline$a(\AA)$ & $6.9336(8)$ & $6.7377(4)$ & $11.5133(8)$ \\
\hline$b(\AA)$ & $14.2452(12)$ & $10.7336(7)$ & $11.5827(6)$ \\
\hline$c(\AA)$ & $18.0427(17)$ & $14.1830(9)$ & $13.3008(10)$ \\
\hline$\alpha\left(^{\circ}\right)$ & 90 & $79.579(2)$ & $72.015(2)$ \\
\hline$\beta\left({ }^{\circ}\right)$ & 90 & $89.838(2)$ & $68.964(2)$ \\
\hline$\gamma\left({ }^{\circ}\right)$ & 90 & $82.976(2)$ & $84.173(2)$ \\
\hline$V\left(\AA^{3}\right)$ & $1782.1(3)$ & $1001.0(1)$ & $1574.5(2)$ \\
\hline$Z$ & 4 & 1 & 2 \\
\hline$\rho\left(\mathrm{g} / \mathrm{cm}^{3}\right)$ & 1.594 & 1.713 & 1.674 \\
\hline$F(000)$ & 872 & 520 & 808 \\
\hline Measured reflections & 6386 & 6951 & 11854 \\
\hline Unique reflections & 2895 & 3582 & 5836 \\
\hline Observed reflections & 1913 & 2791 & 4539 \\
\hline Parameters/restraints & $253 / 1$ & $275 / 7$ & $452 / 2$ \\
\hline$R_{\text {int }}$ & 0.0504 & 0.0287 & 0.0432 \\
\hline Goodness of fit on $F^{2}$ & 1.021 & 1.028 & 1.078 \\
\hline$R_{1}, w R_{2}[I \geq 2 \sigma(I)]^{\mathrm{a}}$ & $0.0508,0.0986$ & $0.0636,0.1618$ & $0.0561,0.1548$ \\
\hline$R_{1}, w R_{2}(\text { all data })^{\mathrm{a}}$ & $0.0877,0.1177$ & $0.0816,0.1804$ & $0.0727,0.1720$ \\
\hline
\end{tabular}

${ }^{\mathrm{a}} R_{l}=\Sigma\left|F_{o}\right|-\left|F_{c}\right| /\left|F_{o}\right|, w R_{2}=\left[\sum w\left(F_{o}^{2}-F_{c}^{2}\right)^{2} / \sum w\left(F_{o}^{2}\right)^{2}\right]^{1 / 2}$. 


\section{5. X-ray Crystallography}

Suitable single crystals of the compounds were selected and mounted on a Bruker Smart 1000 CCD area-detec-

Table 2. Selected bond lengths $(\AA)$ and angles $\left(^{\circ}\right)$ for the compounds

\begin{tabular}{|c|c|c|c|}
\hline \multicolumn{4}{|l|}{$\overline{(\mathrm{HL}) \mathrm{CF}_{3} \mathrm{SO}_{3}}$} \\
\hline \multicolumn{4}{|l|}{ Bond lengths } \\
\hline $\mathrm{C} 7-\mathrm{N} 1$ & $1.276(4)$ & $\mathrm{N} 1-\mathrm{N} 2$ & $1.399(3)$ \\
\hline \multicolumn{4}{|l|}{1} \\
\hline \multicolumn{4}{|l|}{ Bond lengths } \\
\hline C7-N1 & $1.280(6)$ & $\mathrm{N} 1-\mathrm{N} 2$ & $1.382(5)$ \\
\hline $\mathrm{Cu} 1-\mathrm{O} 1$ & $1.878(3)$ & $\mathrm{Cu} 1-\mathrm{N} 1$ & $1.938(4)$ \\
\hline $\mathrm{Cu} 1-\mathrm{O} 3$ & $1.950(4)$ & $\mathrm{Cu} 1-\mathrm{N} 3$ & $1.972(4)$ \\
\hline \multicolumn{4}{|l|}{ Bond angles } \\
\hline $\mathrm{O} 1-\mathrm{Cu} 1-\mathrm{N} 1$ & $92.99(15)$ & $\mathrm{O} 1-\mathrm{Cu} 1-\mathrm{O} 3$ & $89.29(17)$ \\
\hline $\mathrm{N} 1-\mathrm{Cu} 1-\mathrm{O} 3$ & $175.22(17)$ & $\mathrm{O} 1-\mathrm{Cu} 1-\mathrm{N} 3$ & $172.63(15)$ \\
\hline $\mathrm{N} 1-\mathrm{Cu} 1-\mathrm{N} 3$ & $82.26(17)$ & $\mathrm{O} 3-\mathrm{Cu} 1-\mathrm{N} 3$ & $95.87(18)$ \\
\hline \multicolumn{4}{|l|}{2} \\
\hline \multicolumn{4}{|l|}{ Bond lengths } \\
\hline C7-N1 & $1.300(5)$ & $\mathrm{N} 1-\mathrm{N} 2$ & $1.392(4)$ \\
\hline Co1-N1 & $1.872(3)$ & Co1-O1 & $1.878(3)$ \\
\hline Co1-N4 & $1.879(3)$ & Co1-O3 & $1.895(3)$ \\
\hline Co1-N6 & $1.938(3)$ & Co1-N3 & $1.952(3)$ \\
\hline \multicolumn{4}{|l|}{ Bond angles } \\
\hline N1-Co1-O1 & $94.49(12)$ & N1-Co1-N4 & $175.44(13)$ \\
\hline O1-Co1-N4 & $88.84(12)$ & $\mathrm{N} 1-\mathrm{Co} 1-\mathrm{O} 3$ & $88.95(12)$ \\
\hline $\mathrm{O} 1-\mathrm{Co} 1-\mathrm{O} 3$ & $90.53(12)$ & N4-Co1-O3 & $94.15(12)$ \\
\hline N1-Co1-N6 & $94.68(13)$ & O1-Co1-N6 & $89.94(12)$ \\
\hline N4-Co1-N6 & $82.19(13)$ & O3-Co1-N6 & $176.29(12)$ \\
\hline N1-Co1-N3 & $82.68(13)$ & $\mathrm{O} 1-\mathrm{Co} 1-\mathrm{N} 3$ & $176.39(12)$ \\
\hline N4-Co1-N3 & $93.86(13)$ & O3-Co1-N3 & $91.65(12)$ \\
\hline N6-Co1-N3 & $88.06(13)$ & & \\
\hline
\end{tabular}

tor diffractometer with graphite monochromatized Mo-K $\alpha$ radiation $(\lambda=0.71073 \AA$ ) at $298(2) \mathrm{K}$. Data reduction and cell refinement were performed by the SMART and SAINT programs. ${ }^{9}$ Empirical absorption correction was applied by using SADABS. ${ }^{10}$ The structures were solved by direct methods and refined with the full-matrix least-squares technique using SHELXL97. ${ }^{11}$ The non-H atoms in the structures were subjected to refined anisotropic refinement. The amino hydrogen atoms were located from difference Fourier maps and refined isotropically. The remaining hydrogen atoms were located in geometrically and treated with the riding mode. Crystallographic data and experimental details for the compounds are summarized in Table 1. Selected bond lengths and angles for the compounds are listed in Table 2.

\section{6. Antibacterial Test}

Antibacterial activities of the compounds were tested in vitro against Bacillus subtilis, Staphylococcus aureus, Escherichia coli, and Pseudomonas fluorescens using MH medium (Mueller-Hinton medium: casein hydrolysate $17.5 \mathrm{~g}$, soluble starch $1.5 \mathrm{~g}$, beef extract 1000 $\mathrm{mL}$ ). The minimum inhibitory concentrations (MIC) of the test compounds were determined by a colorimetric method using the dye MTT (3-(4,5-dimethylthiazol-2-yl)2,5-diphenyltetrazolium bromide). ${ }^{12} \mathrm{~A}$ solution of the compound $\left(50 \mu \mathrm{g} \mathrm{mL}^{-1}\right)$ in DMSO was prepared and graded quantities of the test compounds were incorporated in specified quantity of sterilized liquid $\mathrm{MH}$ medium. A specified quantity of the medium containing the compound was poured into microtitration plates. Suspension of the microorganism was prepared to contain about $10^{5}$ colony forming units cfu $\mathrm{mL}^{-1}$ and applied to microtitration pla-

Table 3. Distances $(\AA)$ and angles $\left(^{\circ}\right)$ involving hydrogen bonding of the compounds

\begin{tabular}{|c|c|c|c|c|}
\hline$\overline{D-\mathrm{H} \cdots A}$ & $d(D-H)$ & $d(\mathrm{H} \cdots A)$ & $d(D \cdots A)$ & $\overline{\operatorname{Angle}(D-H \cdots A)}$ \\
\hline \multicolumn{5}{|l|}{$\overline{(\mathrm{HL}) \mathrm{CF}_{3} \mathrm{SO}_{3}}$} \\
\hline $\mathrm{N} 3-\mathrm{H} 3 \cdots \mathrm{O} 3^{\mathrm{i}}$ & $0.86(3)$ & $2.00(4)$ & $2.797(4)$ & $156(4)$ \\
\hline $\mathrm{N} 2-\mathrm{H} 2 \cdots \mathrm{O} 5$ & $0.90(1)$ & $1.97(2)$ & $2.847(4)$ & 164(4) \\
\hline $\mathrm{O} 1-\mathrm{H} 1 \cdots \mathrm{O} 2$ & 0.82 & 2.23 & $2.678(3)$ & 114 \\
\hline $\mathrm{O} 1-\mathrm{H} 1 \cdots \mathrm{O} 4^{\mathrm{ii}}$ & 0.82 & 2.14 & $2.814(4)$ & 140 \\
\hline \multicolumn{5}{|l|}{1} \\
\hline $\mathrm{O} 3-\mathrm{H} 3 \mathrm{~A} \cdots \mathrm{O} 4^{\mathrm{iii}}$ & 0.85 & 2.27 & $2.726(7)$ & 114 \\
\hline O3-H3B $\cdots \mathrm{O} 7$ & 0.85 & 1.80 & $2.629(9)$ & 164 \\
\hline $\mathrm{N} 2-\mathrm{H} 2 \cdots \mathrm{O}^{\mathrm{iv}}$ & $0.90(1)$ & $1.97(2)$ & $2.852(6)$ & $167(7)$ \\
\hline $\mathrm{O} 7-\mathrm{H} 7 \mathrm{~A} \cdots \mathrm{O} 3^{\mathrm{v}}$ & 0.85 & 2.44 & $3.230(9)$ & 155 \\
\hline O7-H7B $\cdots \mathrm{O} 2$ & 0.85 & 2.31 & $2.916(9)$ & 128 \\
\hline \multicolumn{5}{|l|}{2} \\
\hline $\mathrm{N} 5-\mathrm{H} 5 \cdots \mathrm{O}^{\mathrm{vi}}$ & $0.89(2)$ & $2.02(3)$ & $2.853(5)$ & $156(5)$ \\
\hline $\mathrm{N} 2-\mathrm{H} 2 \cdots \mathrm{O} 3^{\mathrm{vii}}$ & $0.89(2)$ & $2.61(4)$ & $3.348(4)$ & $141(5)$ \\
\hline $\mathrm{N} 2-\mathrm{H} 2 \cdots \mathrm{O} 4^{\mathrm{vii}}$ & $0.89(2)$ & $2.14(5)$ & $2.803(5)$ & $130(5)$ \\
\hline O8-H8 $\cdots \mathrm{S} 1^{\text {viii }}$ & 0.82 & 3.03 & $3.797(5)$ & 157 \\
\hline 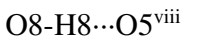 & 0.82 & 2.13 & $2.923(7)$ & 163 \\
\hline
\end{tabular}

Symmetry codes: i) $x, 1 / 2-y,-1 / 2+z$; ii) $-1+x, y, z$; iii) $1-x, 2-y, 1-z$; iv) $1-x, 1-y, 1-z$; v) $-x, 2-y, 1$ $-z$; vi) $x, 1+y, z$; vii) $1-x, 1-y, 1-z$; viii) $x, y, 1+z$. 
tes with serially diluted compounds in DMSO to be tested and incubated at $37{ }^{\circ} \mathrm{C}$ for $24 \mathrm{~h}$. After the MICs were visually determined on each of the microtitration plates, 50 $\mu \mathrm{L}$ of PBS (Phosphate Buffered Saline $0.01 \mathrm{~mol} \mathrm{~L}^{-1}, \mathrm{pH}$ 7.4: $\mathrm{Na}_{2} \mathrm{HPO}_{4} \cdot 12 \mathrm{H}_{2} \mathrm{O} 2.9 \mathrm{~g}, \mathrm{KH}_{2} \mathrm{PO}_{4} 0.2 \mathrm{~g}, \mathrm{NaCl} 8.0 \mathrm{~g}$, $\mathrm{KCl} 0.2 \mathrm{~g}$, distilled water $1000 \mathrm{~mL}$ ) containing $2 \mathrm{mg}$ of MTT was added to each well. Incubation was continued at room temperature for 4-5 h. The content of each well was removed, and $100 \mu \mathrm{L}$ of isopropyl alcohol containing $5 \%$ $1.0 \mathrm{~mol} \mathrm{~L}{ }^{-1} \mathrm{HCl}$ was added to extract the dye. After $12 \mathrm{~h}$ of incubation at room temperature, the optical density (OD) was measured with a microplate reader at $550 \mathrm{~nm}$. The observed MICs are presented in Table 3.

\section{Results and Discussion}

The Schiff base L was readily prepared by condensation reaction of 3-methoxysalicylaldehyde and (3-chlo- ropyridin-2-yl)hydrazine in methanol. Single crystals were formed by the addition of trifluoromethylsulfonic acid, followed by slow evaporation. The copper and cobalt complexes were prepared by the reaction of the Schiff base with copper trifluoromethylsulfonate and cobalt trifluoromethylsulfonate, respectively, in methanol/water solution. As usually observed for the preparation of cobalt complexes, Co ${ }^{\mathrm{II}}$ underwent aerial oxidation to $\mathrm{Co}^{\mathrm{III}}$ in the synthetic route of complex 2. The molar conductivities of the trifluoromethylsulfonate salts of the Schiff base ligand, complex $\mathbf{1}$ and complex 2 measured in methanol at concentration of $10^{-3}$ $\mathrm{M}$ are 253,227 and $208 \Omega^{-1} \mathrm{~cm}^{2} \mathrm{~mol}^{-1}$, indicating the $1: 1$ electrolytic nature of the compounds in solution. ${ }^{13}$

\section{1. Crystal Structure Description of ( $\mathrm{HL}) \mathrm{CF}_{3} \mathrm{SO}_{3}$}

Figure 1 gives perspective view of the compound. The asymmetric unit contains a protonated Schiff base ca-

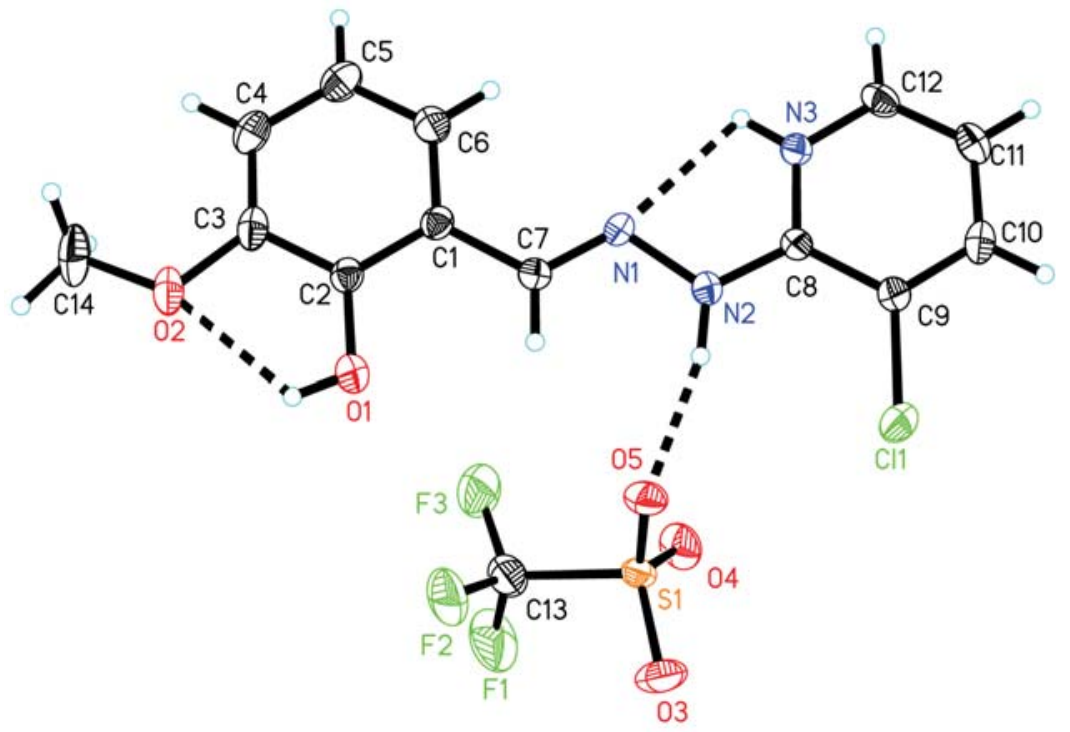

Figure 1. Crystal structure of $(\mathrm{HL}) \mathrm{CF}_{3} \mathrm{SO}_{3}$. Displacement is drawn at the $30 \%$ probability level. Hydrogen bonds are shown as dashed lines.

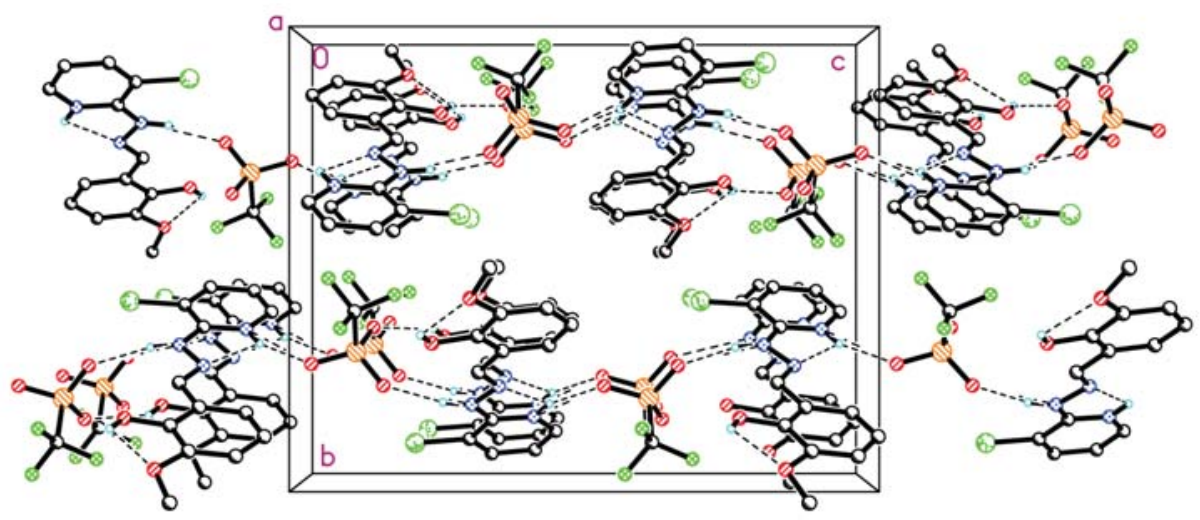

Figure 2. Packing diagram of (HL) $\mathrm{CF}_{3} \mathrm{SO}_{3}$ viewed along the $a$ axis. Hydrogen bonds are shown as dashed lines. 
tion, HL and a trifluoromethylsulfonate. The anion is linked to the cation through intermolecular $\mathrm{N}-\mathrm{H}$... O hydrogen bonds (Table 3). There are two intramolecular $\mathrm{O}-\mathrm{H} \cdots \mathrm{O}$ and $\mathrm{N}-\mathrm{H} \cdots \mathrm{N}$ hydrogen bonds in the Schiff base cation. The dihedral angle between the benzene and pyridine rings is $2.0(3)^{\circ}$. The torsion angles of $\mathrm{C} 1-\mathrm{C} 7-\mathrm{N} 1-\mathrm{N} 2$ and $\mathrm{C} 7-\mathrm{N} 1-\mathrm{N} 2-\mathrm{C} 8$ are $0.5(3)$ and $0.8(3)^{\circ}$, respectively. The bond values of the compound are within normal ranges. ${ }^{14}$ In the crystal structure of the compound, the Schiff base cations are linked by trifluoromethylsulfonate anions through hydrogen bonds (Table 3), giving 2D sheets parallel to the $a c$ plane (Figure 2).

\section{2. Crystal Structure Description of 1}

Figure 3 gives perspective view of complex 1 . The asymmetric unit contains a mononuclear Schiff base copper complex cation, a trifluoromethylsulfonate and half water molecule. The water molecule is linked to the cation through intermolecular $\mathrm{O}-\mathrm{H}$... O hydrogen bonds (Table $3)$. The dihedral angle between the benzene and pyridine rings is $3.6(5)^{\circ}$. The torsion angles of $\mathrm{C} 1-\mathrm{C} 7-\mathrm{N} 1-\mathrm{N} 2$ and C7-N1-N2-C8 are $0.6(5)$ and $1.6(5)^{\circ}$, respectively. The $\mathrm{Cu}$ atom is coordinated by the phenolate $\mathrm{O}$, imino $\mathrm{N}$ and pyridine $\mathrm{N}$ atoms of the Schiff base ligand and one water molecule, giving a square planar geometry. The coordinate bond values of the complex are within normal ranges. ${ }^{15} \mathrm{In}$ the crystal structure of the complex, the Schiff base copper complex cations are linked by trifluoromethylsulfonate anions and water molecules through hydrogen bonds (Table 3 ), giving $2 \mathrm{D}$ sheets parallel to the $a b$ plane (Figure 4).

\section{3. Crystal Structure Description of 2}

Figure 5 gives perspective view of complex 2. The asymmetric unit contains a mononuclear Schiff base cobalt complex cation, a trifluoromethylsulfonate and a methanol molecule. The dihedral angles between the benzene

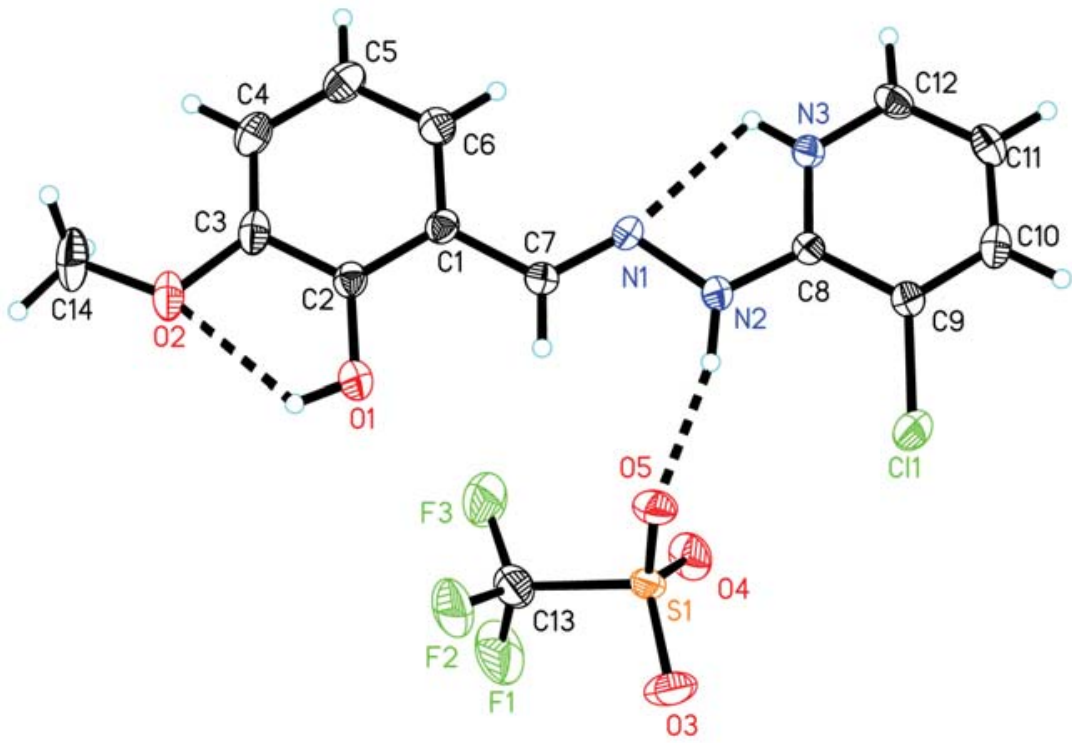

Figure 3. Crystal structure of 1. Displacement is drawn at the $30 \%$ probability level. Hydrogen bonds are shown as dashed lines.

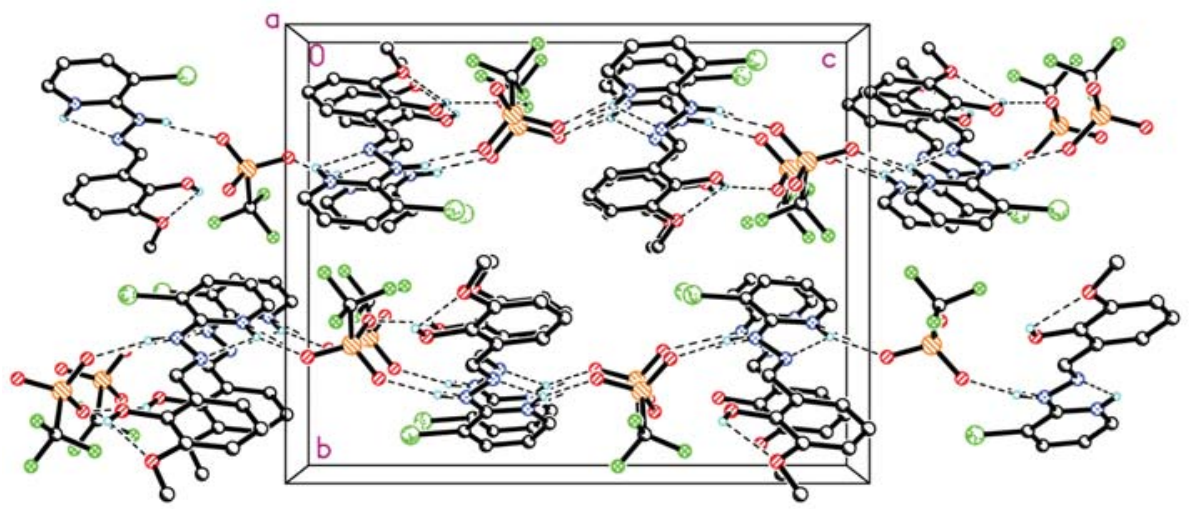

Figure 4. Packing diagram of $\mathbf{1}$ viewed along the $a$ axis. Hydrogen bonds are shown as dashed lines. 
and pyridine rings are $17.7(4)^{\circ}$ for Col molecule and $22.4(4)^{\circ}$ for $\mathrm{Co} 2$ molecule. The torsion angles of C1-C7-N1-N2, C7-N1-N2-C8, C13-C19-N4-N5 and C19-N4-N5-C20 are 6.3(4), 3.8(4), 6.0(4) and 14.5(5) ${ }^{\circ}$, respectively. The Co atom is coordinated by two phenolate $\mathrm{O}$, two imino $\mathrm{N}$ and two pyridine $\mathrm{N}$ atoms from two Schiff base ligands giving an octahedral geometry. The coordinate bond values of the complex are within normal ranges. ${ }^{16}$ In the crystal structure of the complex, adjacent two Schiff base cobalt complex cations are linked through hydrogen bonds (Table 3 ) giving a dimer (Figure 6).

\section{2. IR Spectra}

The weak and broad absorptions centered in the region of 3400-3500 $\mathrm{cm}^{-1}$ are assigned to the stretching vibration of the $\mathrm{O}-\mathrm{H}$ groups of the methanol or water molecules. In the spectrum of $(\mathrm{HL}) \mathrm{CF}_{3} \mathrm{SO}_{3}$, the sharp band at
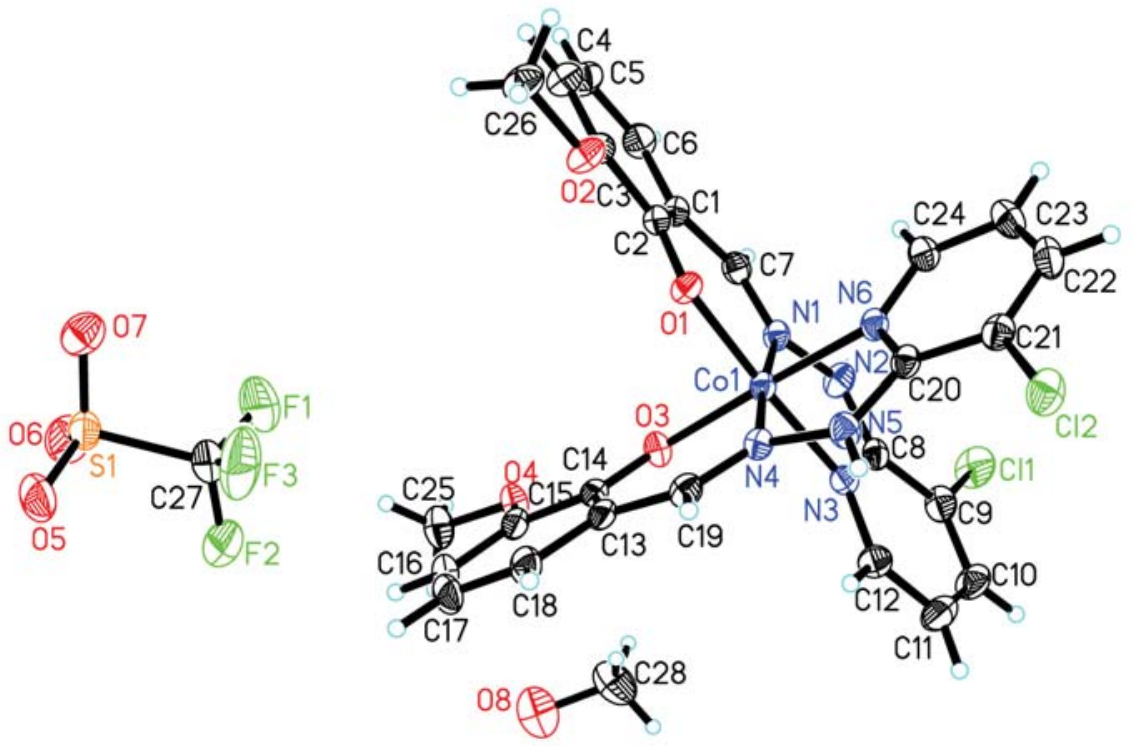

Figure 5. Crystal structure of $\mathbf{2}$. Displacement is drawn at the $30 \%$ probability level.

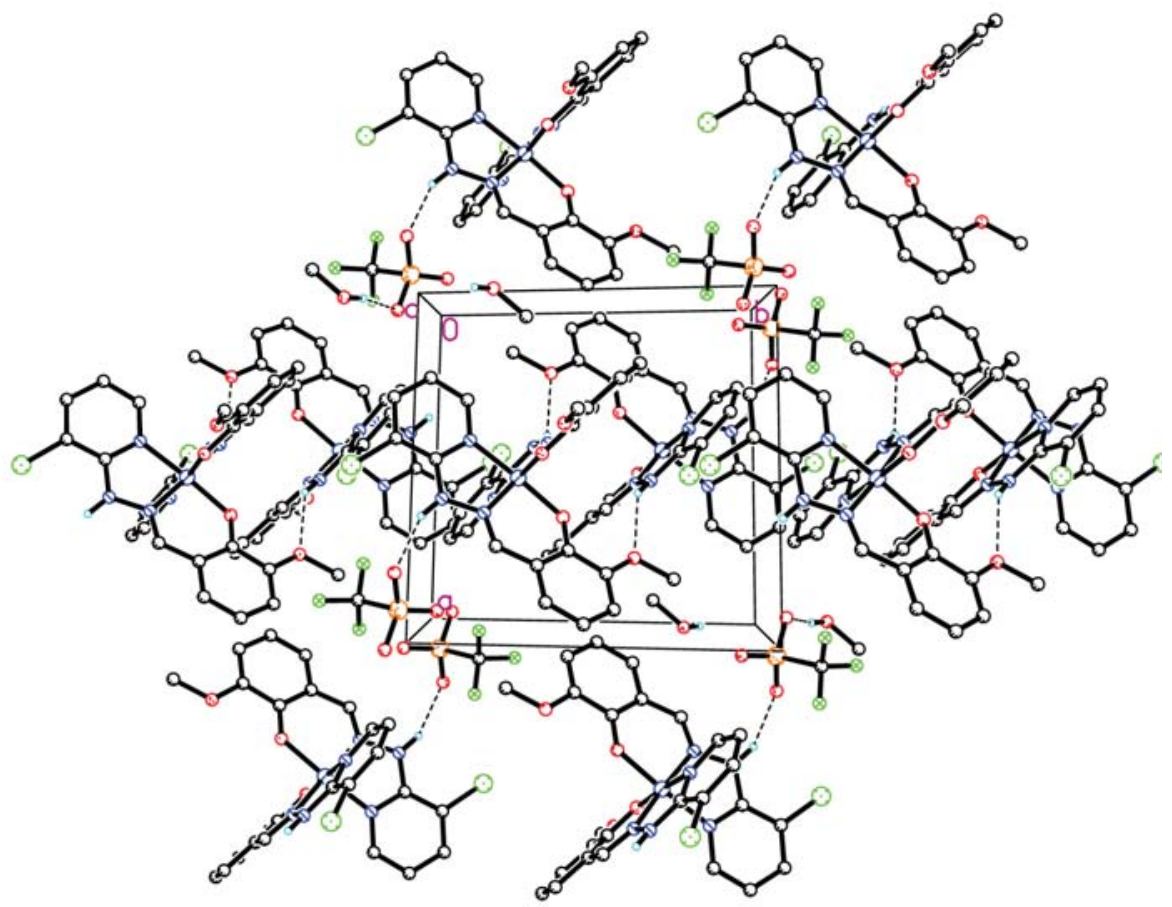

Figure 6. Packing diagram of $\mathbf{2}$ viewed along the $c$ axis. Hydrogen bonds are shown as dashed lines. 
$3300 \mathrm{~cm}^{-1}$ is attributed to the vibration of the $\mathrm{N}-\mathrm{H}$ group of the ligand. This absorption is absent in the spectra of the complexes, indicating the coordination through pyridine nitrogen atom. Several other bands in the range of $2900-3150 \mathrm{~cm}^{-1}$ are assigned to the characteristic absorption of $\mathrm{CH}$ groups. The phenolic $1(\mathrm{C}-\mathrm{O})$ in the spectra of the compounds are observed as medium or weak bands at about $1250 \mathrm{~cm}^{-1}$. The medium band at $1644 \mathrm{~cm}^{-1}$ of (HL) $\mathrm{CF}_{3} \mathrm{SO}_{3}$ is assigned to the azomethine group, $v_{\mathrm{C}=\mathrm{N}}$, which is observed at low wave numbers of $1622 \mathrm{~cm}^{-1}$ for 1 and $1615 \mathrm{~cm}^{-1}$ for 2 , indicating the coordination of the imino nitrogen atoms to the metal atoms. The spectra of the compounds exhibit strong absorption bands at about 1160 and $1070 \mathrm{~cm}^{-1}$, corresponding to the stretching vibrations of the trifluoromethylsulfonate anions.

\section{3. Antibacterial Activities}

The compounds were screened in vitro for antibacterial activities against Bacillus subtilis, Staphylococcus aureus, Escherichia coli, and Pseudomonas fluorescens by the MTT method. The MICs of the compounds against the bacteria are presented in Table 4. Penicillin was used as a reference.

The Schiff base $\mathrm{L}$ and the trifluoromethylsulfate salt of $\mathrm{L}$ show equal activities against the bacterial. In general, both complexes have stronger activities against the bacteria than $\mathrm{L}$ and (HL) $\mathrm{CF}_{3} \mathrm{SO}_{3}$. Complexes 1 and 2 show equal activities against Staphylococcus aureus, while for the other bacteria, complex $\mathbf{1}$ has stronger activities than complex 2 . Even though both complexes have effective activities against Bacillus subtilis, they are much weak than penicillin. However, as for the remaining bacteria, the complexes have stronger activities than penicillin. The trends in the present work are in accordance with those in the literature that metal complexes usually have stronger antibacterial activities than their corresponding ligands. ${ }^{17}$

\section{Conclusions}

A new trifluoromethylsulfonate salt of 2-[(3-chloropyridinium-2-yl)hydrazonomethyl]-6-methoxyphenol and its copper(II) and cobalt(III) complexes have been prepared and characterized. The Schiff base ligand coordinates to the metal atoms through phenolate oxygen, imino nitrogen and pyridine nitrogen atoms. Structures of the compounds are confirmed by infrared spectra and single crystal X-ray determination. The antibacterial activities of the Schiff base and the complexes were assayed. The results indicated that the complexes are potential antibacterial material.

\section{Supplementary Material}

$\mathrm{CCDC}$ reference numbers 1497251 for (HL) $\mathrm{CF}_{3} \mathrm{SO}_{3}$, 1497251 for 1 and 1497254 for $\mathbf{2}$ contain the supplementary crystallographic data for this paper. These data can be obtained free of charge at www.ccdc.cam.ac.uk, or from Cambridge Crystallographic Data Center, 12, Union Road, Cambridge CB2 1EZ, UK; Fax: +44 1223336 033; e-mail: deposit@ccdc.cam.ac.uk.

\section{Acknowledgements}

We gratefully acknowledge the financial support by the Research Program of Science and Technology at Universities of Inner Mongolia Autonomous Region (NJZY238 and NJZY239) and the Inner Mongolia Key Laboratory of Photoelectric Functional Materials.

\section{References}

1. (a) F. D. Popp, W. Kirsch. J. Org. Chem. 1961, 26, 38583862; http://dx.doi.org/10.1021/jo01068a056

(b) T. J. Delia, T. M. Wilcox, R. R. Otteman. J. Heterocyclic Chem. 1979, 16, 1647-1648. http://dx.doi.org/10.1002/jhet.5570160827

2. (a) S. Sumathi, P. Tharmaraj, C. D. Sheela, R. Ebenezer. J. Coord. Chem. 2011, 64, 1707-1717; http://dx.doi.org/10.1080/00958972.2011.580844

(b) Z. H. Chohan, M. UI-Hassan, K. M. Khan, C. T. Supuran. J. Enzym. Inhib. Med. Chem. 2005, 20, 183-188. http://dx.doi.org/10.1080/14756360500043257

Table 4. Antibacterial activities

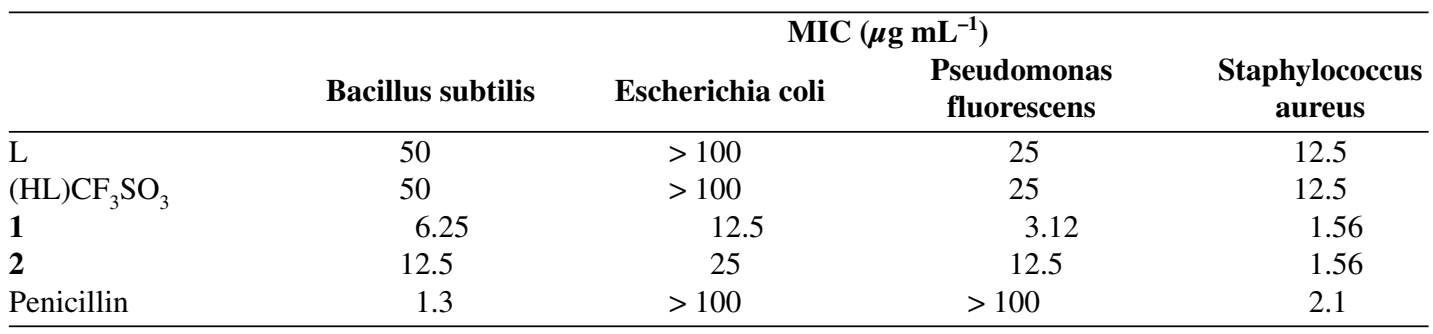


3. M. A. Vazquez-Fernandez, M. I. Fernandez-Garcia, G. Gonzalez-Riopedre, M. Maneiro, M. J. Rodriguez-Douton. $J$. Coord. Chem. 2011, 64, 3843-3858. http://dx.doi.org/10.1080/00958972.2011.633164

4. (a) A. Lalehzari, J. Desper, C. J. Levy. Inorg. Chem. 2008, 47, 1120-1126; http://dx.doi.org/10.1021/ic702015u

(b) N. Raman, S. Johnson Raja, A. Sakthivel. J. Coord. Chem. 2009, 62, 691-709;

http://dx.doi.org/10.1080/00958970802326179

(c) A. D. Garnovskii, I. S. Vasilchenko, D. A. Garnovskii, B. I. Kharisov. J. Coord. Chem. 2009, 62, 151-204. http://dx.doi.org/10.1080/00958970802398178

5. (a) R. S. Joseyphus, M. S. Nair. J. Coord. Chem. 2009, 62, 319-327; http://dx.doi.org/10.1080/00958970802236048

(b) N. Nishat, Rahis-Ud-Din, S. Dhyani. J. Coord. Chem. 2009, 62, 996-1004;

http://dx.doi.org/10.1080/00958970802339651

(c) M. S. Refat, I. M. El-Deen, Z. M. Anwer, S. El-Ghol. J. Coord. Chem. 2009, 62, 1709-1718;

http://dx.doi.org/10.1080/00958970802684205

(d) R. Vafazadeh, A. C. Willis, M. M. Heidari, N. Hasanzade. Acta Chim. Slov. 2015, 62, 122-129;

http://dx.doi.org/10.17344/acsi.2014.797

(e) S.-S. Qian, X. Zhao, J. Wang, Z. You. Acta Chim. Slov. 2015, 62, 828-833.

6. (a) H. Li, Z.-J. Zhong, X.-Z. You, W. Chen. J. Coord. Chem. 1997, 42, 271-281;

http://dx.doi.org/10.1080/00958979708022857

(b) V. Mougel, P. Horeglad, G. Nocton, J. Pecaut, M. Mazzanti. Angew. Chem. Int. Ed. Engl. 2009, 48, 8477-8480; http://dx.doi.org/10.1002/anie.200903457

(c) X.-L. Ma, Z.-L. You, Transit. Met. Chem. 2008, 33, 961965. http://dx.doi.org/10.1007/s11243-008-9136-1

7. (a) J. Gao, Y.-G. Liu, Y. Zhou, L. M. Boxer, F. R. Woolley, R. A. Zingaro. ChemBioChem 2007, 8, 332-340;

http://dx.doi.org/10.1002/cbic.200600299

(b) T. W. Failes, T. W. Hambley. J. Inorg. Biochem. 2007, 101, 396-403.

http://dx.doi.org/10.1016/j.jinorgbio.2006.11.003

8. M. Zhang, D.-M. Xian, H.-H. Li, J.-C. Zhang, Z.-L. You. Aust. J. Chem. 2012, 65, 343-350.
9. SMART and SAINT. Area Detector Control and Integration Software, Siemens Analytical X-Ray Systems, Inc., Madison, Wisconsin, USA, 1996.

10. G. M. Sheldrick, SADABS. Program for Empirical Absorption Correction of Area Detector Data, University of Göttingen, Germany, 1996.

11. G. M. Sheldrick. SHELXTL V5.1 Software Reference Manual, Bruker AXS, Inc., Madison, Wisconsin, USA, 1997.

12. J. Meletiadis, J. F. G. M. Meis, J. W. Mouton, J. P. Donnelly, P. E. Verweij. J. Clin. Microbiol. 2000, 38, 2949-2954.

13. W. J. Geary. Coord. Chem. Rev. 1971, 7, 81-122. http://dx.doi.org/10.1016/S0010-8545(00)80009-0

14. (a) T. Tunc, M. Sari, R. Yagbasan, H. Tezcan, E. Sahin. Acta Crystallogr. 2003, C59, o192-o193;

(b) M. Chang, A. Kobayashi, K. Nakajima, H.-C. Chang, M. Kato. Inorg. Chem. 2011, 50, 8308-8317. http://dx.doi.org/10.1021/ic2008396

15. (a) K. Ghosh, P. Kumar, V. Mohan, U. P. Singh, S. Kasiri, S. S. Mandal. Inorg. Chem. 2012, 51, 3343-3345; http://dx.doi.org/10.1021/ic2016676

(b) K. Ghosh, P. Kumar, N. Tyagi, U. P. Singh, V. Aggarwal, M. C. Baratto. Eur. J. Med. Chem. 2010, 45, 3770-3779.

http://dx.doi.org/10.1016/j.ejmech.2010.05.026

16. (a) J. M. Holland, C. A. Kilner, M. Thornton-Pett, M. A. Halcrow. Polyhedron 2001, 20, 2829-2840;

http://dx.doi.org/10.1016/S0277-5387(01)00892-0

(b) C. W. G. Ansell, J. Lewis, P. R. Raithby. J. Chem. Soc. Dalton Trans. 1982, 2557-2559.

http://dx.doi.org/10.1039/dt9820002557

17. (a) A.-G. Xie, Y. Qu, M.-M. Wang, G.-Q. Gan, H. Chen, Z.D. Lin, D. Zhen. J. Coord. Chem. 2009, 62, 2268-2275; http://dx.doi.org/10.1080/00958970902822127 (b) M. A. Phaniband, S. D. Dhumwad. J. Coord. Chem. 2009, 62, 2399-2410; http://dx.doi.org/10.1080/00958970902803341 (c) S. Sumathi, P. Tharmaraj, C. D. Sheela, R. Ebenezer, P. S. Bhava. J. Coord. Chem. 2011, 64, 1673-1682; http://dx.doi.org/10.1080/00958972.2011.579116

(d) M. Ghosh, M. Fleck, B. Mahanti, A. Ghosh, G. Pilet, D. Bandyopadhyay. J. Coord. Chem. 2012, 65, 3884-3894. http://dx.doi.org/10.1080/00958972.2012.727990

\section{Povzetek}

Pripravili smo novo trifluorometilsulfonatno sol 2-[(3-kloropiridin-2-il)hidrazonometil]-6-metoksifenola, (HL) $\mathrm{CF}_{3} \mathrm{SO}_{3}$, in njena bakrova(II) in kobaltova(III) kompleksa $\left[\mathrm{CuL}\left(\mathrm{OH}_{2}\right)\right] \mathrm{CF}_{3} \mathrm{SO}_{3} \cdot 0.5 \mathrm{H}_{2} \mathrm{O}$ (1) in $\left[\mathrm{CoL}_{2}\right] \mathrm{CF}_{3} \mathrm{SO}_{3} \cdot \mathrm{CH}_{3} \mathrm{OH}(\mathbf{2})$ ter jih okarakterizirali s fizikalno-kemijskimi metodami in monokristalno rentgensko analizo. Trifluorometilsulfonatni anion je prisoten v vseh treh spojinah. Cu atom v kompleksu $\mathbf{1}$ je koordiniran preko fenolatnega $\mathrm{O}$, imino $\mathrm{N}$ in piridinskega $\mathrm{N}$ atoma liganda $\mathrm{L}$ in ima kvadratno-planarno geometrijo. Co atom v kompleksu 2 je koordiniran preko dveh fenolatnih $\mathrm{O}$, dveh imino $\mathrm{N}$ in dveh piridinskih $\mathrm{N}$ atomov dveh L ligandov in ima oktaedrično geometrijo. Vsem triem spojinam smo določili in vitro antibakterijsko aktivnost. 